\title{
Microencapsulation of probiotics and its applications with prebiotic in Pacific white shrimp larvae through Artemia sp.
}

\section{Mikroenkapsulasi probiotik dan aplikasinya dengan prebiotik pada larva udang vaname melalui Artemia sp.}

\author{
Dian Eka Ramadhani ${ }^{1}$, Widanarni1 ${ }^{*}$, Sukenda ${ }^{1}$ \\ 'Department of Aquaculture, Faculty of Fisheries and Marine Sciences, IPB University \\ Dramaga Bogor, West Java 16680 \\ "Corresponding author: widanarni@yahoo.com
}

(Received January 31, 2019; Accepted July 4, 2019)

\begin{abstract}
This study aimed to produce microencapsulated probiotic Pseudoalteromonas piscicida (1Ub) and evaluate it with prebiotic mannan-oligosaccharide (MOS) through the enrichment of Artemia sp., on bacterial population, growth performances, immune responses, and disease resistance of Pacific white shrimp larvae. Microencapsulation of probiotic was done by the freeze-drying method. The shrimp larvae were reared for 13 days and fed by the Artemia sp. enriched with microcapsule of probiotic $1 \mathrm{Ub}(10 \mathrm{~g} / \mathrm{L})$, prebiotic MOS $(12 \mathrm{mg} / \mathrm{L})$, synbiotic, and control without administration of microencapsulated probiotic and prebiotic, including negative (C-) and positive $(\mathrm{C}+)$ control. On the day 14, all of the experimental shrimp larvae except $\mathrm{C}$ - were challenged through immersion method with Vibrio harveyi MR5339 (107 CFU/mL). This study showed that the administration of microcapsule of probiotic $1 \mathrm{Ub}$, prebiotic MOS, and synbiotic through the enrichment of Artemia sp. could increase the bacteria population, growth performances, immune responses, and disease resistance of Pacific white shrimp larvae. Moreover, synbiotic treatment demonstrated the best result compared to other treatments.
\end{abstract}

Keywords: probiotic, prebiotic, synbiotic, Pacific white shrimp, microencapsulation

\begin{abstract}
ABSTRAK
Penelitian ini bertujuan untuk membuat mikrokapsul probiotik Pseudoalteromonas piscicida (1Ub) dan mengevaluasinya dengan prebiotik mannan-oligosaccharides (MOS) melalui pengayaan Artemia sp. terhadap populasi bakteri, performa pertumbuhan, respons imun dan resistensi penyakit pada larva udang vaname. Mikroenkapsulasi probiotik dilakukan dengan metode freeze-drying. Larva udang dipelihara selama 13 hari dan diberi pakan Artemia sp. yang telah diperkaya dengan mikrokapsul probiotik $1 \mathrm{Ub}(10 \mathrm{~g} / \mathrm{L})$, prebiotik MOS (12 $\mathrm{mg} / \mathrm{L}$ ), sinbiotik, dan kontrol tanpa penambahan mikrokapsul probiotik dan prebiotik, termasuk kontrol negatif (C-) dan positif (C+). Pada hari ke-14, seluruh larva udang percobaan kecuali C- diuji tantang melalui metode perendaman dengan Vibrio harveyi MR5339 (107 CFU/mL). Hasil penelitian menunjukkan bahwa pemberian mikrokapsul probiotik 1Ub, prebiotik MOS, dan sinbiotik melalui pengayaan Artemia sp. dapat meningkatkan populasi bakteri, performa pertumbuhan, respons imun, dan resistensi penyakit pada larva udang vaname. Selain itu, perlakuan sinbiotik menunjukkan hasil terbaik dibandingkan perlakukan lainnya.
\end{abstract}

Kata kunci : probiotik, prebiotik, sinbiotik, udang vaname, mikroenkapsulasi 


\section{INTRODUCTION}

Pacific white shrimp Litopenaeus vannamei is one of the important aquaculture commodities that are widely cultured both in Indonesia and around the world. Indonesia is the fourth largest shrimp producer after China, India, and Vietnam, which accounts for about $4.6 \%$ of the world shrimp production (FAO, 2014). Production of Pacific white shrimp needs a high-quality larva in adequate quantity and time. However, bacterial disease induced by Vibrio harveyi has remained a great challenge in the production of Pacific white shrimp larvae in Indonesia and generally called as vibriosis. Recent study (Huang et al., 2016) reported that Vibrio bacteria were predominant in the digestive tract of Pacific white shrimp during the postlarvae (80\%) and juvenile stages (89.1$94.2 \%$ ). Vibriosis can cause serious mortality in Pacific white shrimp (Raja et al., 2017) and the mortality rate can reach $100 \%$ (Karunasagar et al., 1994).

The utilization of antibiotics has been proposed to control the disease outbreak. However, the technique was reported to promote serious problems associated with antibioticresistant bacteria, residual existence, and food safety issues (Zhang et al., 2014). Stalin et al., (2016) reported that Vibrio harveyi has resistant to various antibiotics such as ampicillin, cefaclor, ciprofloxacin, penicilin, rifampicin, chloramphnicol, and vancomycin. The administration of probiotic, prebiotic, and synbiotic could be a preventive alternative approach that was more eco-friendly and beneficial in shrimp culture.

Probiotic is a living microorganism that has beneficial effects on the host and enhances microbial balance in the digestive tract, feed efficiency, and environmental condition (Nayak, 2010). Several studies reported that probiotics can improve the survival rate and immune responses in Pacific white shrimp (Zokaeifar et al., 2014; Liu et al., 2010), digestive enzyme activity, nutrient digestibility and growth performances in Tilapia (Putra et al.,2015; Utami et al., 2015). Meanwhile, prebiotic is a non-digestible food component and promotes advantageous effects to the host through inducing intestinal bacterial growth and activity, which may improve the host health (Cerezuela et al., 2011). Prebiotics known for aquaculture includes arabinoxylanoligosaccharide (AXOS), fructo-oligosaccharide (FOS), galactooligosaccharides (GOS), mannan- oligosaccharide (MOS), xylooligosaccharides (XOS), inulin, and $\beta$-glucan (Akhter et al., 2015; Hoseinifar et al., 2019). Some researchers reported that prebiotic MOS can improve health and fish production (Torrecillas et al., 2014), growth, survival rate, intestinal flora and gut surface area of lobster Panulirus homarus (Huu et al., 2014), as well as protection in the Pacific white shrimp upon pathogen exposure (Rungrassamee et al., 2014). Other studies reported that a combination of probiotic and prebiotic, recognized as synbiotic, could exhibit synergistic action (Huynh et al., 2017). Merrifield et al., (2010) suggested that synbiotic may produce great beneficial effects rather than the application of individual prebiotic or probiotic. Several studies showed that synbiotics can improve health and growth of Sebastes schlegelii (Rahimnejad et al., 2017), digestibility, feed absorption, specific growth rate, and digestive enzyme activities in common carp (Dehaghani et al., 2015), growth performances and immune responses in Pacific white shrimp (Oktaviana et al., 2014; Zubaidah et al., 2015).

The present study reported that probiotic Pseudoalteromonas piscicida $1 \mathrm{Ub}$ (fresh culture) improved the growth performances of Pacific shrimp larvae (Hamsah et al., 2017a). However, its fresh culture still showed some disadvantages such as limited storability and difficult application. Microencapsulation is one of the alternative techniques to protect probiotic against extreme conditions. In this approach, bacterial cells were surrounded by an encapsulated membrane which reduced degradation and loss of the cells, thus the bacteria would survive and could be released at appropriate sites in the digestive tract of the host (Martin et al., 2015). The present study aimed to investigate the effects of microencapsulated probiotic $P$. piscicida $1 \mathrm{Ub}$ and prebiotic mannanoligosaccharide (MOS) through Artemia sp. enrichment on bacterial growth, growth performance, immune responses, and resistance of Pacific white shrimp larvae.

\section{MATERIALS AND METHODS}

\section{Preparation of probiotic, prebiotic, synbiotic, and $V$. harveyi}

Probiotic P. piscicida $1 \mathrm{Ub}$ was isolated from Pacific white shrimp nauplii (Widanarni et al., 2009) and was marked with antibiotic rifampicin at a dose of $50 \mu \mathrm{g} / \mathrm{mL}\left(1 \mathrm{Ub} \mathrm{Rf}^{\mathrm{R}}\right)$. Probiotic $P$. piscicida $1 \mathrm{Ub}$ was cultured in $50 \mathrm{~mL}$ of seawater complete broth (SWC, $0.5 \mathrm{~g}$ bactopeptone, $0.1 \mathrm{~g}$ 
yeast extract, $0.3 \mathrm{~mL}$ glycerol, $75 \mathrm{~mL}$ seawater, 25 $\mathrm{mL}$ distilled water), incubated in the thermoshaker at $140 \mathrm{rpm}$ for $18 \mathrm{~h}$ at $25^{\circ} \mathrm{C}$, and followed by upscaling (1:10). Bio-MOS (Alltech Inc., KY USA) was used as prebiotic which contained mannan-oligosaccharide (MOS) derived from the cell walls of Saccharomyces cerevisiae with a composition of $30 \%$ crude protein, $1.4 \%$ crude fat and $13 \%$ crude fiber). Probiotic and prebiotic were combined to produce synbiotic. Antibioticresistant $V$. harveyi MR5339 (V. harveyi MR5339 $\mathrm{Rf}^{\mathrm{R}}$ ) was used in the challenge test. $V$. harveyi was cultured in TCBS (thiosulphate citrate bile-salt sucrose) media (HiMedia Laboratories) for $24 \mathrm{~h}$, and then cultured in SWC broth and incubated in the thermoshaker at $140 \mathrm{rpm}$ for $10 \mathrm{~h}$ at $25^{\circ} \mathrm{C}$.

\section{Probiotic microencapsulation}

The microencapsulation process included the preparation of probiotic bacteria and coating materials. The coating materials used were $10 \%$ sterilized maltodextrin $(100 \mathrm{~g}$ maltodextrin and $1 \mathrm{~L}$ distilled water) and whey protein. The proportion of probiotics, whey protein, and maltodextrin was made at 1:1:0.1 ( $/ \mathrm{v} / \mathrm{w})$, respectively (Munaeni $e t$ $a l .$, 2014). Furthermore, the probiotic was dried by using a freeze dryer (LABCONCO) at $-50^{\circ} \mathrm{C}$ for $24 \mathrm{~h}$. The microcapsule of probiotic was then transferred in a container and stored in the refrigerator at $-20^{\circ} \mathrm{C}$.

\section{Feeding treatments}

The feed was Artemia sp. with appropriate size to shrimp larvae, high nutrition, and high digestibility. The treatments were positive and negative control (C+, C-: without enriched Artemia sp.), probiotic $P$. piscicida $1 \mathrm{Ub}$ (10 $\mathrm{g} / \mathrm{L} ; 10^{6} \mathrm{CFU} / \mathrm{g}$ ), prebiotic MOS $12 \mathrm{mg} / \mathrm{L}$, and synbiotic.

\section{Hatching and enrichment of Artemia sp.}

Artemia sp. cysts were hatched in $2 \mathrm{~g} / \mathrm{L}$ seawater (salinity $30 \mathrm{~g} / \mathrm{L}$ ), and the Artemia sp. were harvested after $24 \mathrm{~h}$. Artemia sp. were enriched at the instar 2 stage (approximately 4 $\mathrm{h}$ after harvesting) in a plastic tank containing $1 \mathrm{~L}$ seawater (salinity $30 \mathrm{~g} / \mathrm{L}$ ) at densities of 100 individual/mL (Hamsah et al., 2017a). Microencapsulated probiotic, prebiotic MOS and synbiotic were added and aerated for $4 \mathrm{~h}$. The enrichment dose was determined as previously described by Hamsah et al., (2017a). Artemia sp. were harvested using a plankton net and washed with disinfected seawater, while remaining Artemia sp. were stored in the refrigerator at $4^{\circ} \mathrm{C}$ for further use on the same day.

\section{Larvae rearing}

Pacific white shrimp larvae (mean initial length of $4.72 \pm 0.25 \mathrm{~mm}$ ) were obtained from PT. Suri Tani Pemuka (STP), Carita, Banten. The larvae were reared in 15 aquariums $\left(60 \times 30 \times 35 \mathrm{~cm}^{3}\right.$; volume $10 \mathrm{~L}$ ) at densities of 200 individuals per aquarium. Completely randomized design (CRD) was arranged with triplicates. The larvae were reared from mysis 3 (M3) to postlarvae (PL) 12 and fed by enriched Artemia sp. 3-4 individuals for M3 larvae and 8-10 individuals for PL1-PL12 at five times daily $(06.00 \mathrm{am}, 10.00 \mathrm{am}, 02.00 \mathrm{pm}$, $06.00 \mathrm{pm}$, and $10.00 \mathrm{pm}$ ). The dose of Artemia sp. was determined as previously described by Nimrat et al., (2011). During rearing, water quality was controlled at $29-30^{\circ} \mathrm{C}, \mathrm{pH} 8.33-8.53$, salinity 30-33 g/L, and total ammonia nitrogen (TAN) $0.58-0.69 \mathrm{ppm}$. To maintain the water quality, water was replaced at $5-10 \%$ by disinfected seawater and siphoned every three days. At the end of the experimental period, a challenge test using V. harveyi MR5339 $\mathrm{Rf}^{\mathrm{R}}\left(10^{7} \mathrm{CFU} / \mathrm{mL}\right)$ was infected to PL 13 of all treatments using the immersion method, which was conducted in a container containing $1 \mathrm{~L}$ seawater at densities of 20 individual/L. Meanwhile, a negative control was immersed with an equal volume of the SWC broth medium. During the challenge test (5 days), shrimp larvae were fed by non-enriched Artemia sp., and the number of their deaths was monitored.

\section{Determination of product percentage and probiotic viability}

Determination of product percentage and probiotic viability included product percentage after drying, bacterial viability after drying, the percentage of bacterial viability after microencapsulation, and probiotic viability after storage. All these parameters were determined according to the method constructed by Utami $e t$ al., (2015).

\section{Determination of bacterial population}

The spread plate method was used to determine bacterial count, total probiotic P. piscicida $1 \mathrm{Ub}$ $\mathrm{Rf}^{\mathrm{R}}$, persumtive Vibrio and V. harveyi (Ludemann et al., 2015). Five shrimp larvae $0.1 \mathrm{~g}$ were crushed and homogenized in $0.9 \mathrm{~mL}$ PBS (phosphate buffer saline; $0.8 \mathrm{~g} \mathrm{NaCl}, 0.02 \mathrm{~g} \mathrm{KH}_{2} \mathrm{PO}_{4}, 0.15$ $\mathrm{g} \mathrm{Na}_{2} \mathrm{HPO}_{4}, 0.02 \mathrm{~g} \mathrm{KCl}, 100 \mathrm{~mL}$ distilled water). 
The serial dilution was then made (1:10). The suspension $(50 \mu \mathrm{L})$ was spread onto SWC-agar to count total bacteria and onto SWC-agar+Rif onto count total probiotic $P$. piscicida $1 \mathrm{Ub} \mathrm{Rf}^{\mathrm{R}}$, TCBS medium to count total Vibrio and TCBS+Rif medium to count $V$. harveyi MR5339 Rf .

\section{Determination of growth performance}

Growth performance was determined at the end of the rearing period, including survival rate (Nimrat et al., 2011), specific growth rate (Nimrat et al., 2011), and absolute length growth (Dehaghani et al., 2015).

\section{Immune responses}

The immune responses were determined at the end of the experimental period (PL12) and the fifth days after the challenge test. The observed parameter included total haemocyte count (THC), phenoloxidase activity (PO), and respiratory burst activity (RB). The procedure for the determination of THC followed the method previously described by Tampangalloo et al. (2013), while the procedure for PO and RB assay follows the method from Hyunh et al. (2011), respectively.

\section{Larval resistance against $\boldsymbol{V}$. harveyi}

The larval resistance was determined by enumeration of shrimp larvae survival, presumptive Vibrio and V. harveyi MR5339 $\mathrm{Rf}^{\mathrm{R}}$ during five days of challenge test.

\section{Statistical analysis}

Data on growth performances, immune responses, and survival rates were statistically evaluated by one way-ANOVA in SPSS (version 16). Significant differences between means were compared using Duncan multiple range tests (DMRT) at a confidence interval of $95 \%$. Descriptive analysis was used to evaluate the product percentage and bacterial viability, bacterial population in the Pacific white shrimp larvae, and daily mortality.

\section{RESULTS}

The analysis on product percentage and bacterial viability resulted in product percentage after drying 10\% (100 g dried probiotic obtained from $1 \mathrm{~L}$ probiotic suspension), bacterial viability after drying $7.38 \times 10^{5} \mathrm{CFU} / \mathrm{g}$, probiotic viability after microencapsulation $63 \%$, and probiotic viability during four months storage $91.04 \%$.

The results on the bacterial population demonstrated that synbiotic treatment showed the highest total bacteria $\left(4.26 \times 10^{8} \mathrm{CFU} /\right.$ larvae $)$ and probiotic $P$. piscicida $1 \mathrm{Ub} \mathrm{Rf}^{\mathrm{R}}\left(1.51 \times 10^{5}\right.$ CFU/larvae). Meanwhile, the highest persumtive

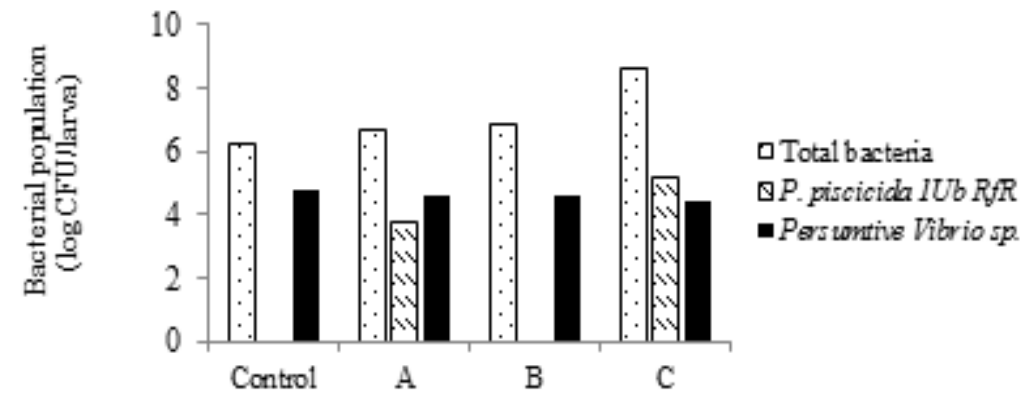

Figure 1. The bacterial population in Pacific white shrimp larvae after treatment; administration of microcapsule probiotic $P$. piscicida $1 \mathrm{Ub} 10 \mathrm{~g} / \mathrm{L}$ (A), prebiotic MOS $12 \mathrm{mg} / \mathrm{mL}$ (B), and synbiotic (C) through the enrichment of Artemia sp.
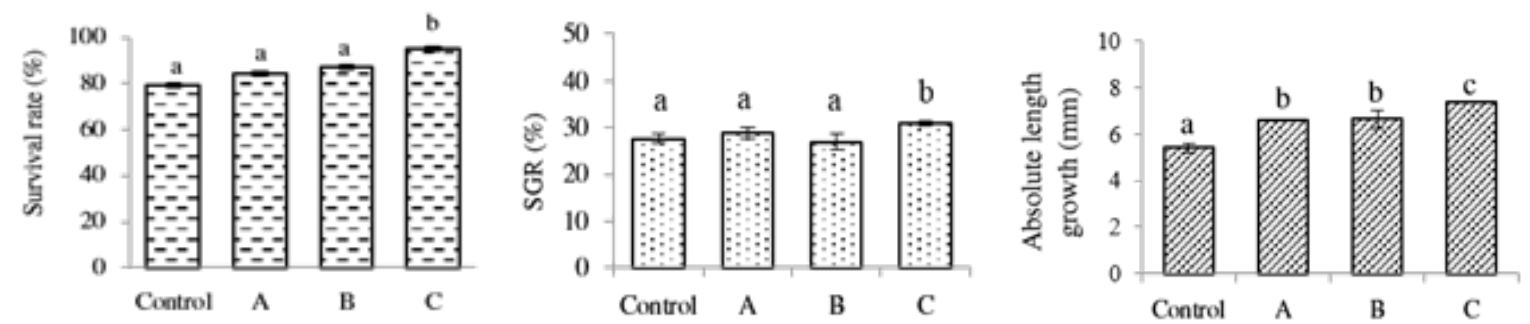

Figure 2. Growth performance; survival rate (a), SGR (b), absolute length growth (c) of Pacific white shrimp larvae after treatments. Different letters on the same bar (mean \pm SD) indicated significant differences (DMRT; $\mathrm{P}<0.05$ ). Administration of microencapsulated probiotic $P$. piscicida $1 \mathrm{Ub} 10 \mathrm{~g} / \mathrm{L}$ (A); prebiotic MOS $12 \mathrm{mg} / \mathrm{L}$ (B), synbiotic (probiotic P. piscicida $1 \mathrm{Ub} 10 \mathrm{~g} / \mathrm{L}+$ prebiotic MOS $12 \mathrm{mg} / \mathrm{L}$ ) (C) through enrichment Artemia sp. 
Vibrio was attributed to control treatment $(\mathrm{C}+$ and C-) $6 \times 10^{4} \mathrm{CFU} /$ larvae, and synbiotic treatment resulted in the lowest Vibrio population $2.8 \times 10^{4}$ CFU/larvae (Figure 1).

The results on growth performances showed that synbiotic treatment had highest survival rate after treatment $(95.00 \pm 1.72 \%)$ and significantly different $(\mathrm{P}<0.05)$ with control $(79.00 \pm 0.01 \%)$, probiotic $(84.00 \pm 0.05 \%)$, and prebiotic $(87.00$ $\pm 0.04 \%$ ). Whereas between control, probiotic, and prebiotic there was not significantly different $(\mathrm{P}>0.05)$. The highest specific growth rate (SGR) was shown by synbiotic treatment $(31.00$ $\pm 0.50 \%)$ and significantly different $(\mathrm{P}<0.05)$ with control $(27.60 \pm 0.94 \%)$, probiotic $(28.80 \pm$ $1.19 \%)$, and prebiotic $(26.90 \pm 1.72 \%)$. Whereas the other treatments there was not significantly different $(\mathrm{P}>0.05)$. Synbiotic treatment also showed the highest absolute length growth (7.35 $\pm 0.01 \mathrm{~mm})$ and significantly different $(\mathrm{P}<0.05)$ with control $(5.41 \pm 0.18 \mathrm{~mm})$, probiotic $(6.58$ $\pm 0.04 \mathrm{~mm})$, and prebiotic $(6.65 \pm 0.39 \mathrm{~mm})$. Whereas probiotic and prebiotic treatment was not significantly different $(\mathrm{P}>0.05)$, but it was significantly different $(\mathrm{P}<0.05)$ with control (Figure 2).

The highest total hemocyte count (THC) after treatment was shown by synbiotic $(4.80 \pm$ $1.04 \times 10^{5}$ cell $\left./ \mathrm{mL}\right)$ and significantly different with control $\left(3.47 \pm 0.12 \times 10^{5}\right.$ cell $\left./ \mathrm{mL}\right)$, probiotic $\left(2.30 \pm 0.92 \times 10^{5} \mathrm{cell} / \mathrm{mL}\right)$, and prebiotic $(3.00 \pm$ $0.00 \times 10^{5} \mathrm{cell} / \mathrm{mL}$ ). Whereas the other treatments there was not significantly different $(\mathrm{P}>0.05)$. THC has increased after being challenged with $V$. harveyi MR5339 $\mathrm{Rf}^{\mathrm{R}}$. The highest THC after challenged was synbiotic $\left(10.83 \pm 1.27 \times 10^{5}\right.$ cell/ $\mathrm{mL})$ and significantly different $(\mathrm{P}<0.05)$ with negative $\left(4.30 \pm 1.25 \times 10^{5} \mathrm{cell} / \mathrm{mL}\right)$ and positive
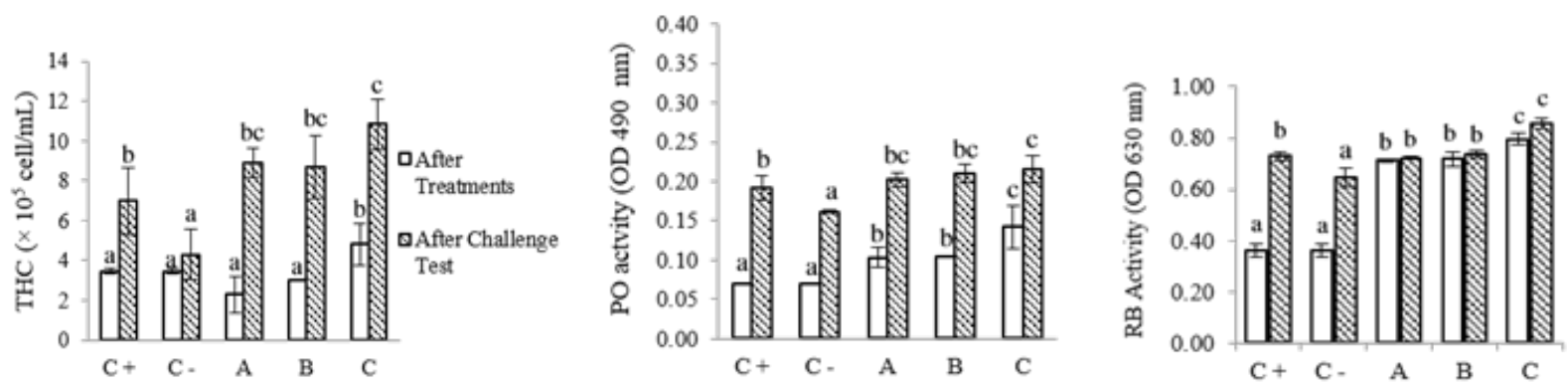

Figure 3. Immune responses; THC (a), PO activity (b), RB activity (c) of Pacific white shrimp larvae after treatments and after challenged by $V$. harveyi. Different letters on the same bar $(m e a n \pm S D)$ indicated significant differences (DMRT; P<0.05). Administration of microencapsulated probiotic P. piscicida $1 \mathrm{Ub} 10 \mathrm{~g} / \mathrm{L}$ (A); prebiotic MOS $12 \mathrm{mg} / \mathrm{L}$ (B), synbiotic (probiotic P. piscicida $1 \mathrm{Ub} 10 \mathrm{~g} / \mathrm{L}$ + prebiotic MOS $12 \mathrm{mg} / \mathrm{L}$ ) (C) through enrichment Artemia sp.
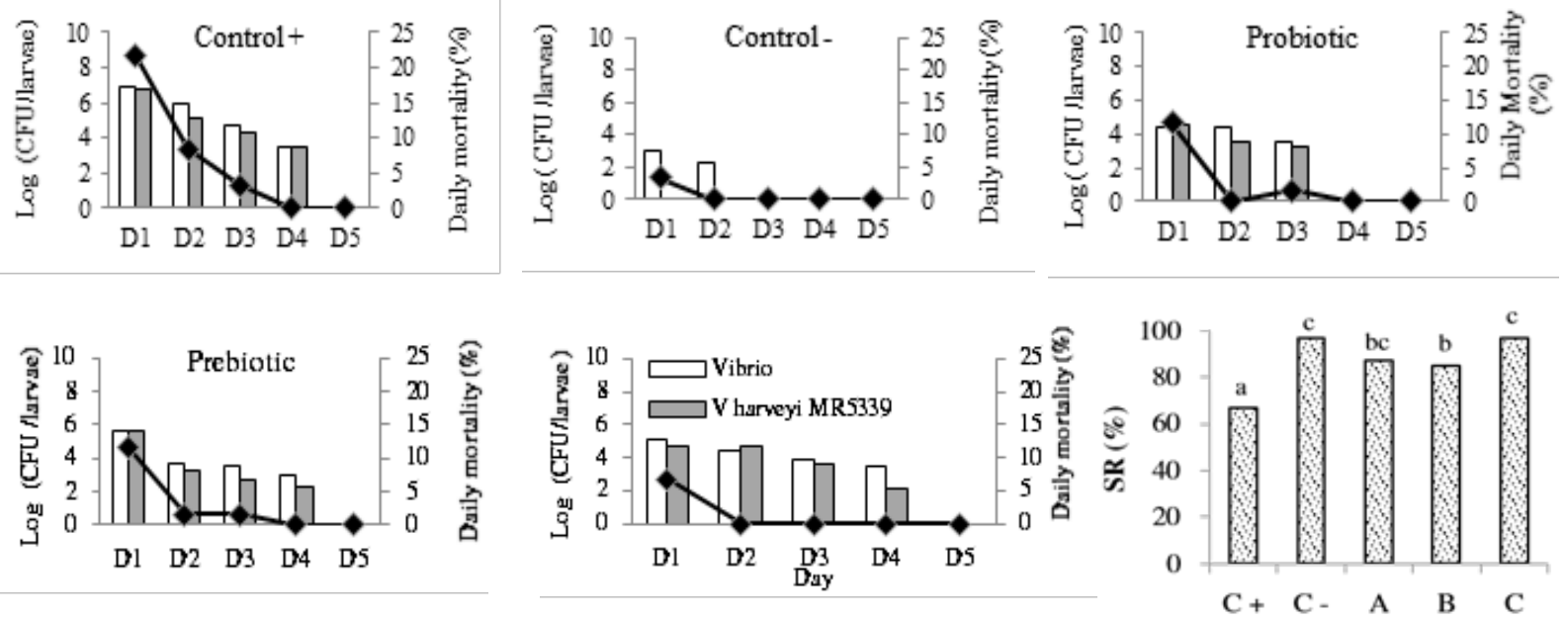

Figure 4. After challenge test using pathogenic bacteria V. harveyi MR5339 RfR; daily mortality pattern, presumptive Vibrio and $V$. harveyi in Pacific white shrimp larvae, as well as the survival rate of Pacific white shrimp larvae for 5 days. Different letters on the same bar (mean \pm SD) indicated significant differences (DMRT; $\mathrm{P}<0.05$ ). Administration of microencapsulated probiotic $P$. piscicida $1 \mathrm{Ub} 10 \mathrm{~g} / \mathrm{L}$ (A); prebiotic MOS $12 \mathrm{mg} / \mathrm{L}$ (B), synbiotic (probiotic P. piscicida $1 \mathrm{Ub} 10 \mathrm{~g} / \mathrm{L}+$ prebiotic MOS $12 \mathrm{mg} / \mathrm{L}$ ) (C) through enrichment Artemia sp. 
$\left(6.97 \pm 1.67 \times 10^{5} \mathrm{cell} / \mathrm{mL}\right)$ control. Whereas probiotic, prebiotic, and synbiotic there was not significantly different $(\mathrm{P}>0.05)$ (Figure 3$)$.

Synbiotic treatment also showed the highest phenoloxidase (PO) activity $(0.28 \pm 0.03$ OD 490 $\mathrm{nm})$ after treatment and significantly different $(\mathrm{P}<0.05)$ with positive and negative control $(0.14$ $\pm 0.00 \mathrm{OD} 490 \mathrm{~nm})$, probiotic $(0.21 \pm 0.01 \mathrm{OD}$ $490 \mathrm{~nm})$, and prebiotic $(0.21 \pm 0.00$ OD $490 \mathrm{~nm})$. Whereas probiotic and prebiotic treatments there were not significantly different $(\mathrm{P}>0.05)$. However, both are significantly different $(\mathrm{P}<0.05)$ with the positive and negative control. PO activity has increased after challenged by $V$. harveyi MR5339 $\mathrm{Rf}^{\mathrm{R}}$. The higher PO activity after challenge test were shown by synbiotic $(0.45 \pm 0.02$ OD 490 $\mathrm{nm})$, prebiotic $(0.43 \pm 0.01$ OD $490 \mathrm{~nm})$, and probiotic $(0.38 \pm 0.01 \mathrm{OD} 490 \mathrm{~nm})$ treatments as well as significantly different $(\mathrm{P}<0.05)$ with negative $(0.36 \pm 0.00 \mathrm{OD} 490 \mathrm{~nm})$ and positive $(0.37 \pm 0.02$ OD $490 \mathrm{~nm})$ control (Figure 3$)$.

The highest respiratory burst (RB) activity after treatment was shown by synbiotic treatment $(0.79$ $\pm 0.02 \mathrm{OD} 630 \mathrm{~nm}$ ) and significantly different $(\mathrm{P}<0.05)$ with probiotic $(0.71 \pm 0.00$ OD 630 $\mathrm{nm})$, prebiotic $(0.72 \pm 0.01 \mathrm{OD} 630 \mathrm{~nm})$, positive and negative control $(0.36 \pm 0.01 \mathrm{OD} 630 \mathrm{~nm})$. Whereas probiotic and prebiotic treatments there were not significantly different $(\mathrm{P}>0.05)$. However, both are significantly different $(\mathrm{P}<0.05)$ from the positive and negative control. RB activity also increased after challenged by $V$. harveyi MR5339 $R f^{R}$. The highest RB activity after challenge test was shown by synbiotic treatment $(0.86 \pm 0.12$ OD $630 \mathrm{~nm})$ and significantly different $(\mathrm{P}<0.05)$ with probiotic $(0.72 \pm 0.01 \mathrm{OD} 630 \mathrm{~nm})$, prebiotic $(0.74 \pm 0.01$ OD $630 \mathrm{~nm})$, and positive $(0.73 \pm$ $0.04 \mathrm{OD} 630 \mathrm{~nm})$ as well as negative $(0.64 \pm 0.01$ OD $630 \mathrm{~nm}$ ) control (Figure 3).

After the challenge test, the highest number of the shrimp larvae death, total Vibrio, and Vibrio harveyi were attributed to control positive, while the lowest one was attributed to the synbiotic treatment. After challenge test, the highest survival rate $(\mathrm{P}<0.05)$ was obtained in synbiotic treatment $(97.00 \pm 0.06 \%)$ and significantly different $(\mathrm{P}<0.05)$ with positive control $(67.00$ $\pm 0.03 \%)$ and prebiotic treatment $(85.00 \pm 0.05$ $\%)$. Whereas probiotic treatment $(87.00 \pm 0.06$ $\%)$ was not significantly different $(\mathrm{P}>0.05)$ with prebiotic and synbiotic treatment (Figure 4).

\section{DISCUSSIONS}

The results of probiotic microencapsulation demonstrated high product percentage and probiotic viability after microencapsulation and four months of storage. The high yield of encapsulated probiotic indicates a protective effect of coating materials namely maltodextrin and whey protein. The coating material might contribute to stabilizing cell viability during the storage process. Maltodextrin is one of the coating materials that had water-soluble properties and the ability to absorb water, as well as maltodextrin contains polyanion that only able to protect bioactive compounds on the first layer (Kurniasih et al., 2018). Recent research reported that whey protein can interact with a wide range of active molecules and can protect probiotic bacteria before their targeted release in the digestive tract of the host (Martin et al., 2015). Moreover, whey protein is a polycation that able to protect as the second layer after maltodextrin (Mishra, 2016). The coating materials from this polyanion and polycation will form spiral tissue to protect bio-active content (Saloko et al., 2014) so that encapsulated probiotic had a long-time release.

The present study revealed that the administration of synbiotic showed a lower population of Vibrio compared to control (C+ and C-), indicating that synbiotic treatment could inhibit the development of Vibrio. The high total bacteria and probiotic $P$. piscicida $1 \mathrm{Ub}$ in synbiotic treatment indicate that the probiotic bacteria could utilize MOS for their growth and successfully adapted through attaching and colonizing in the digestive tract of shrimp larvae. Wongsasak et al. (2014) reported that probiotic encapsulation could enhance probiotic colonization in the digestive tract of Pacific white shrimp larvae. Goh et al. (2015) reported that during synbiotic administration, prebiotics that has been incorporated into synbiotics will be hydrolyzed in the digestive tract of the host and will be used as a carbon source to increase the probiotic bacteria biomass. Therefore, the high proliferation of probiotic bacteria supported by prebiotic MOS causes the growth of Vibrio to decrease. This result is related to the ability of probiotic bacteria Bacillus spp. can inhibit the proliferation of Vibrio in European lobster larvae supported by prebiotic mannan-oligosaccharide (MOS) (Daniels et al., 2010). Recent research 
also reported that shrimp fed the probioticsupplemented diet significantly reduced the abundance of Vibrio spp. and increase the abundance of lactic acid bacteria found in the intestinal tract of shrimp (Vieira et al., 2016).

After treatment, synbiotic produces the best growth performances compared to other treatments. This result indicates that there might be probiotic $P$. piscicida $1 \mathrm{Ub}$ can utilize prebiotic MOS with aid of enzymatic activity enhanced the digestive system of shrimp larvae to more easily absorb the nutrition for their growth, so that the growth performance is increasing. Wang et al. (2019) reported that higher enzyme activites in the digestive tract enhance digestive capabilities and growth performance of the host. The digestive enzyme is a useful comparative indicator for food utilization, digestive capacity, and growth performance of the host (Cerezuela et al., 2011). The previous study has shown that probiotic $P$. piscicida $1 \mathrm{Ub}$ was able to produce protease, lipase, amylase, and mannanase enzymes (Hamsah et al., 2017b). Several studies have shown that probiotics with exo-enzyme activities could significantly improve the growth performance of the Tilapia (Liu et al., 2017; Han et al., 2015), so this might be related to the production of digestive enzymes in Pacific white shrimp larvae. Zhang et al. (2010) reported that dietary supplementation of $B$. subtilis $\left(10^{7} \mathrm{CFU} / \mathrm{g}\right)$ and $0.25 \%$ fructooligosaccharide (FOS) significantly increased SGR and disease resistance of sea cucumber against Vibrio splendidus infection. The results of this study also showed that synbiotic could increase the survival rate after synbiotic administration. It is thought that prebiotics are utilized by targeted probiotic in intestinal and some metabolites are released such as chain fatty acids (SCFAs), amino acids, or polyamines that may boost the health of host as well as it will increase the survival rate of the host (Hyunh et al., 2017).

Before the challenge test, the high value of THC, activity of PO and RB indicated defense activity by shrimp larvae against the invasive pathogen. After the challenge test, the high value of THC demonstrated the proliferation and movement of haemocyte cells in the tissues infected by Vibrio harveyi MR5339. Maftuch et al., (2013) reported that the open haemocyte circulation system could distribute haemocytes in both the vascular system and tissues. This study showed that the administration of synbiotic could increase immune responses (THC, PO and RB activity) better than other treatments. Similarly,
Nurhayati et al. (2015) also reported that dietary supplementation of synbiotic through the feed for 30 days could increase THC, PO and RB activity of Pacific white shrimp. Hyunh et al. (2017) reported that synbiotics can trigger encapsulation and phagocytosis processes in shrimp. Furthermore, the high PO activity demonstrated the enhanced capability of the shrimp in distinguishing foreign particles. Wongsasak et al. (2014) reported that synbiotic-supplemented feed also increased PO activity of Pacific white shrimp. Respiratory burst (RB) defined the release of foreign particles by phagocytes involving degradative enzyme released to phagosome (oxygen-dependent killing). Rodriguez and Le Moullac (2000) explained that increased RB activity was associated with higher phagocytosis activity in the host. Zhang et al. (2011) reported that the conjoining of isomalto-oligosaccharide (IMO) and Bacillus ( $B$. lichenformis and $B$. subtilis) promoted to enhance RB activity on Penaeus japonicas.

The mode of synbiotic actions against invaders has demonstrated by Hyunh et al. (2017). Cerenius et al. (2004) reported that the cell wall components of probiotic bacteria such as $\beta$-glucan and lipopolysaccharides contribute to immunostimulatory effects through patternrecognition proteins (PRPs) that are recognized and bound the foreign molecules that have pathogen-associated molecular patterns (PAMPs). Hamsah et al. (2019) reported that the administration of fresh culture P. piscicida $1 \mathrm{Ub}$ and prebiotic MOS in Pacific white shrimp produces the gene expression of lipopolysaccharide and $\beta$-glucan-binding protein (LGBP) higher than control. Lipoposacharide and $\beta$-glucan-binding protein (LGBP) is pattern recognition proteins that play an important role in innate immunity of crustaceans such as activation of the proPO system to recognize and bound foreign molecules and pathogens (Amparyup et al., 2013). Additionally, Arockiaraj et al. (2015) reported that mannose-binding lectin (MBL) that mediates cellular recognition has also been reported. MBL is a class of protein with specific carbohydrate recognition such as sugar and plays an important role in the immune system (Drickamer et al., 1988; Medzhitov et al., 2002). Moreover, MOS can stimulate mannose receptors and MBL by liver secretion triggering a complete cascade stimulating the immune system of rainbow trout Oncorhynchus mykiss (Rodriguez-Estrada et al., 2009). The mode of action of several kinds of research indicates that the increase of shrimp 
immune responses is related to the performance of the shrimp immune system which is triggered by the synergistic of probiotic and prebiotic action.

The high survival rate in synbiotic treatment after the challenge test demonstrated the increased immune responses of Pacific white shrimp larvae. This also might be due to by reduction of total bacterial Vibrio and $V$. harveyi MR5339 $\mathrm{Rf}^{\mathrm{R}}$ in Pacific white shrimp larvae. The ability of $P$. piscicda $1 \mathrm{Ub}$ in utilizing MOS for their growth also contributed to the competition of selecting appropriate sites for attachment and colonization in the digestive tract of the Pacific white shrimp larvae, thus reducing the growth of Vibrio and V. harveyi MR5339 $\mathrm{Rf}^{\mathrm{R}}$. Zhang et al. (2011) reported that dietary administration of synbiotic (consisting of isomalto-oligosaccharide (IMO) and Bacillus (B. lichenformis and B. subtilis) could reduce the population of Vibrio on shrimp Penaeus japonicas. Moreover, it is similar to recent research (Hyunh et al., 2019) that the administration of synbiotics (Lactobacillus plantarum and galactooligosaccharides) able to reduce the Vibrio species as well as GOS supported the selected probiotic and non-endemic pathogenic bacteria in the digestive tract of shrimp. Russo et al. (2012) also reported that probiotic bacteria can protect the host from pathogens due to competitive exclusion for adhesion sites.

In conclusion, microencapsulation technology can produce dry products with the viability of probiotic bacteria that stable during 4 months and can protect probiotic bacteria from the process of making and storing, as well as applying to shrimp through Artemia sp. Besides, this technology also supports provides beneficial effects on probiotic bacteria to be able to utilize the prebiotic optimally in the digestive tract of Pacific white shrimp larvae. The administration of probiotic P. piscicida $1 \mathrm{Ub} \mathrm{Rf}^{\mathrm{R}}$, prebiotic MOS, and synbiotic through the enrichment of Artemia sp. demonstrated beneficial effects on the bacterial population, growth performances, immune responses, and disease resistance of Pacific white shrimp larvae against $V$. harveyi MR5339 $\mathrm{Rf}^{\mathrm{R}}$. This present study concluded that the best result was synbiotic treatment.

\section{ACKNOWLEDGMENT}

We would like to thank the Laboratory of Fish Health Management at the Department of Aquaculture, Faculty of Fisheries and Marine
Science and Food Processing Pilot Plant of SEAFAST (South East Asian Food and Agricultural Science and Technology) Center that have provided research facilities.

\section{REFERENCES}

Akhter N, Wu B, Memon AM, Mohsin M. 2015. Probiotics and prebiotics associated with aquaculture: a review. Fish and Shellfish Immunology 45: 733-741.

Amparyup P, Charoensapsri W, Tassanakajon A. 2013. Prophenoloxidase system and its role in shrimp immune responses against major pathogens. Fish and Shellfish Immunology 34: 990-1001.

Arockiaraj J, Chaurasia MK, Kumaresan V, Palanisamy R, Harikrishnan R, Pasupuleti M, Kasi M. 2015. Macrobrachium rosenbergii mannose-binding lectin: synthesis of MrMBL-N20 and MrMBL-C16 peptides and their antimicrobial characterization, bioinformatics and relative gene expression analysis. Fish and Shellfish Immunology 43: 364-474.

Cerenius L, Soderhal. 2004. The prophenoloxidase-activating system in invertebrates. Immunological Review 198: 116-126.

Cerezuela R, Meseguer J, Esteban MA. 2011. Current knowledge in synbioticuse for fish aquaculture. Aquaculture Research and Development. S1: 008.

Daniels CL, Merrifield DL, Boothroyd DP, Davies SJ, Factor JR, Arnold KE. 2010. Effect of dietary Bacillus spp. And mannanoligosaccharides (MOS) on Europan lobster (Homarus gammarus L.) larvae growth performance, gut morphology, and gut microbiota. Aquaculture 304: 49-57.

Dehaghani PG, Baboli M J, Moghada A T, Nejad S Z, Pourfarhadi M. 2015. Effect of synbiotic dietary supplementation on survival, growth performance, and digestive enzyme activities of common carp Cyprinus carpio fingerlings. Czech Journal of Animal Science 60: 224-232.

Drickamer K. 1988. Two distinct classes of carbohydrate-recognition domains in animal lectins. Journal of Biology Chemistry 263: 9557-9560.

[FAO] Food and Agriculture Organization of the United Nations. 2014. The state of world fisheries and aquaculture 2014. http://www. fao.org/3/a-i3720e.pdf. [25 April 2019]. 
Goh Y J, Klaenhammer T R. 2015. Genetics mechanisms of prebiotic oligosaccharide metabolism in probiotic microbes. Annual Review of Food Science and Technology 6: 137-156.

Hamsah, Widanarni, Alimuddin, Yuhana M, Junior M Z. 2017a. Bacterial population, activity of enzymes and growth rate of pacific white shrimp larvae administered Pseudoalteromonas piscicida and mannan oligosaccharide through bioencapsulation of Artemia sp.. Research Journal of Microbiology 12: $128-136$.

Hamsah, Widanarni, Alimuddin, Yuhana M, Junior MZ. 2017b. The nutritional value of Artemia sp. enriched with probiotic Pseudoalteromonas piscicida and the prebiotic mannan oligosaccharide. Bioflux 10: 8-17.

Hamsah, Widanarni, Alimuddin, Yuhana M, Junior M Z, Hidayatullah D. 2019. Immune response and resistance of Pacific white shrimp larvae administered probiotic, prebiotic, and synbiotic through the bio-encapsulation of Artemia sp. Aquaculture International 27: 567-580.

Han B, Long W, He J, Liu Y, Si Y, Tian L. 2015. Effects of dietary Bacillus licenformis on growth performance, immunological parameters, intestinal morphology and resistance of juvenile Nile tilapia (Oreochromis niloticus) to challenge infections. Fish and Shellfish Immunology 46: 225-231.

Hoseinifar SH, Hossein M, Paknejad H, Safari R, Jafar A, Yousefi M, Doan HV, Mazanzadeh MT. 2019. Enhanced mucosal immune responses, immune-related genes and growth performance in common carp Cyprinus carpio juveniles fed dietary Pediococcus acidilactici MA18/5M and raffinose. Developmental and Comparative Immunology 94: 59-65.

Huang Z, Li X, Wang L, Shao Z. 2016. Changes in the intestinal bacterial community during the growth of white shrimp, Litopenaeus vannamei. Aquaculture Research. 47: $1737-1746$.

Huu HD, Jones CM. 2014. Effects of dietary mannan oligosaccharide supplementation on juvenile spiny lobster Panulirus homarus (Palinuridae). Aquaculture $432:$ 258-264.

Huynh TG, Yeh ST, Lin YC, Shyu JF, Chen LL, Chen JC. 2011. White shrimp Litopenaeus vannamei immersed in seawater containing Sargassum hemiohyllum var. Chinese powder and its extract showed increased immunity and resistance against Vibrio alginolyticus and white spot syndrome virus. Fish and Shellfish Immunology 31: 286-293.

Huynh TG, Shiu YL, Nguyen TP, Truong QP, Chen JC, Liu CH. 2017. Current applications, selection, and possible mechanisms of actions of synbiotics in improving the growth and health status in aquaculture: a review. Fish and Shellfish Immunology 64: 367-382.

Hyunh TG, Hu SY, Chiu C S, Truong Q P, Liu C H. 2019. Bacterial population in intestines of white shrimp, Litopenaeus vannamei fed a synbiotic containing Lactobacillus plantarum and galactooligosaccharide. Aquaculture Research 00: 1-11.

Karunasagar I, Pai R, Malathi GR, Indriani K. 1994. Mass mortality of Penaeus monodon larvae due to antibiotic-resistant Vibrio harveyi infection. Aquaculture 128: 203-209.

Kurniasih RA, Dewi EN, Purnamayanti L. 2018. Effect coating materials on the characteristics of chlorophyll microcapsules from Caulerpa racemosa. IOP Conf. Earth and Environmental Science 116: 012030.

Liu KF, Chiu CH, Shiu YL, Cheng W, Liu CH. 2010. Effects of the probiotic, Bacillus subtilis E20 on the survival, development, stress tolerance, and immune status of white shrimp Litopenaeus vannamei larvae. Fish Shellfish Immunology 28: 837-844.

Liu H, Wang S, Yan C, Guo X, Cao Z, Zhang Y, Liu S, Yuan W, Zhu W, Zheng Y, Guo W, Zhou Y. 2017. Dietary administration of Bacillus subtilis HAINUP40 enhances growth, digestive enzyme activities, innate immune responses and disease resistance of tilapia Oreochromis niloticus 60: 326-333.

Ludemann L R, Rebecca L W H. 2015. Standard operating policy/procedure, standard bacterial plate count. United States Department of Agriculture Center for Veterinary Biologics. $1-6 \mathrm{p}$.

Maftuch, Prasetio E, Sudianto A, Rozik M, Nurdiyani R, Sanusi E, Nursyam H, Fariedah F, Marsoedi, Murachman. 2013. Improvement of innate immune responses and defense activity in tiger shrimp (Penaeus monodon Fab.) by intramuscular administration of the outer membrane protein Vibrio alginolyticus. SpringerPlus 2: 432.

Martin MJ, Lara-Villoslada F, Ruiz MA, Morales. 2015. Microencapsulation of bacteria: A review of different technologies and their impact on the probiotic effects. Innovative Food Science and Emerging Technologies 27: 15-25. 
Medzhitov R, Janeway C A. 2002. Decoding the patterns of self and nonself by the innate immune system. Science 296: 298-300.

Merrifield DL, Dimitroglou A, Foey A, Davies SJ, Baker RTM, Bogwald J, Castex M, Ringo E. 2010. The current status and future focus of probiotic and prebiotic applications for salmonids. Aquaculture 302: 1-18.

Mishra M. 2016. Handbook of encapsulation and controlled release. CRC Press. 235-242.

Munaeni W, Yuhana M, Widanarni. 2014. Effect of micro-encapsulated synbiotic at different frequencies for luminous vibriosis control in white shrimp Litopenaeus vannamei. Microbiology Indonesia 3: 73-80.

Nayak S K. 2010. Probiotics and immunity: A Fish Perspective. Fish and Shellfish Immunology 29: 2-14.

Nimrat ST, Boonthai V,Vuthiphandchai. 2011. Effect of probiotic form, composition of and mode of probiotic administration on rearing of Pacific white shrimp Litopenaeus vannamei larvae and postlarvae. Animal Feed Science and Technology 169: 244-258.

Nurhayati D, Widanarni, Yuhana M. 2015. Dietary synbiotic influence on the growth performances and immune responses to coinfection with infectious myonecrosis virus and Vibrio harveyi in Litopenaeus vannamei. Journal of Fisheries and Aquatic Science 10: 13-23.

Oktaviana A, Widanarni, Yuhana M. 2014. The use of synbiotics to prevent imnv and Vibrio harveyi co-infection in Litopenaeus vannamei. Hayati Journal of Biosciences 21: 127-134.

Putra NP, Widanarni. 2015. Screening of amylolytic bacteria as candidates of probiotics in Tilapia (Oreochromis sp.). Research Journal of Microbiology 10: 1-13.

Rahimnejad S, Fransisco A, Guardiola, Leclercq E, Esteban M A, Castex M, Sotoudeh E, Lee S M. 2017. Effects of dietary supplementation with Pediococcus acidilactici MA18/5M, galactooligosaccharide and their synbiotic on growth, innate immunity and disease resistance of rockfish (Sebastes schlegelii). Aquaculture 482: 36-44.

Raja RA, Sridhar R, Balachandran C, Palanisammi A, Ramesh S, Nagarajan K. 2017. Pathogenicity profile of Vibrio parahaemolyticus in farmed Pacific white shrimp, Penaeus vannamei. Fish and Shellfish Immunology 67: 368-381.

Rodriguez J, Le-Moullac G. 2000. State of the art of immunological tools and health control of penaeid shrimp. Aquaculture 191: 109-119.
Rodriguez-Estarda U, Satoh S, Haga Y, Fushimi H, Sweetman J. 2009. Effects of single and combined supplementation of Enterococcus faecalis, mannan-oligosaccharide and polyhydroxybutyrate acid on growth performance and immune response of rainbow trout Oncorhynchus mykiss. Aquaculture Science 57: 609-617.

Rungrassamee W, Kingcha Y, Srimarut Y, Mainbunkaew S, Karoonuthaisiri N, Visessanguan W. 2014. Mannan oligosaccharides from copra meal improves survival of the Pacific white shrimp (Litopenaeus vannamei) after exposure to Vibrio harveyi. Aquaculture 434: 403-410.

Russo P, Lopez P, Capozzi V, de Palencia PF, Duenas M T, Spano G, Fiocco D. 2012. Beta-glucans improve growth, viability and colonizatin of probiotic microorganisms. International Journal of Molecular Science 13: 6026-6039.

Saloko S, Darmaji P, and Pranoto Y. 2014. Antioxidative and antimicrobial activities of liquid smoke nanocapsules using chitosan and maltodextrin and its application on tuna fish preservation. Journal of Food Bioscience 7: 71-79.

Stalin N, Srinivasan P. 2016. Molecular characterization of antibiotic-resistant Vibrio harveyi isolated from shrimp aquaculture environment in the southeast coast of India. Microbial Pathogenesis. 97: 110-118.

Tampangallo B R, Pakidi C S, Rantetondok A. 2013. The tiger shrimp fry are maintained with several types of Rica probiotic and their resistance to pathogenic bacteria $V$. harveyi. Proceedings of the Aquaculture Prosiding Forum Inovasi Teknologi Akuakultur. Balai Penelitian dan Pengembangan Budidaya Air Payau. Sulawesi Selatan, Indonesia. 863-874.

Torrecillas S, Montero D, Izquierdo M. 2014. Improved health and growth of fish fed mannan oligosaccharides: potential mode of action. Fish and Shellfish Immunology 36: 525-544.

Utami DAS, Widanarni, Suprayudi MA. 2015. Quality of dried Bacillus NP5 and its effect on growth performance of tilapia Oreochromis niloticus. Pakistan Journal of Biological Sciences 18: 88-93.

Vieira FDN, Jatoba A, Mourino JLP, Neto CC, Silva JSD, Seiffert WQ, Soares M, Vinatea LA. 2016. Use of probiotic-supplemented diet on Pacific white shrimp. Revista Brasileira de Zootecnia 45: 203-207.

Wang A, Ran C, Wang Y, Zhang Z, Qianwen D, 
Yang Y, Olsen RE, Ringo E, Bindle J, Zhou Z. 2019. Use of probiotics in aquaculture of China - a review of the past decade. Fish and Shellfish Immunology 86: 734-755.

Widanarni, Tepu I, Sukenda, Setiawati M. 2009. Selection of probiotic bacteria for vibriosis biocontrol in tiger shrimp larvae, Penaeus monodon uses a shared culture method. Journal of Riset Akuakultur 4: 95-105.

Wongsasak U, Chaijamrus S, Kumkhong S, Boonanuntanasarn S. 2014. Effect of dietary supplementation with $\beta$-glucan and synbiotics on immune gene expression and immune parameters under ammonia stress in Pacific white shrimp. Aquaculture 436: 179-187.

Zhang Q, Ma H, Mai K, Zhang W, Liufu Z, Xu W. 2010. Interaction of dietary Bacillus subtilis and fructooligosaccharide on the growth performance, non-specific immunity of sea cucumber, Apostichopus japonicus. Fish and Shellfish Immunology 29: 204-211.

Zhang Q, Tan B, Mai K, Zhang W, Ma H, Ai Q, Wang X,LiufuZ.2011.Dietary administration of Bacillus (B. licheniformis and B. subtilis) and isomaltooligosaccharide influences the intestinal microflora, immunological parameters and resistance against Vibrio alginolyticus in shrimp, Penaeus japonicus (Decapoda: Penaeidae). Aquaculture Research 42: 943-952.

Zhang Q, Yu H, Tong T, Tong W, Dong L, Xu M. 2014. Dietary supplementation of Bacillus subtilis and fructooligosaccharide enhance the growth, non-specific immunity of juvenile ovate pompano, Trachinotus ovatus and its disease resistance against Vibrio vulnificus. Fish and Shellfish Immunology 38: 7-14.

Zokaeifar H, Babaei N, Saad CR, Kamarudin MS, Sijam K, Balcazar JL. 2014. Administration of Bacillus subtilis strains in the rearing water enhances the water quality, growth performance, immune response, and resistance against Vibrio harveyi infection in juvenile white shrimp, Litopenaeus vannamei. Fish Shellfish Immunology 36: 68-74.

Zubaidah A, Yuhana M, Widanarni. 2015. Encapsulated synbiotic dietary supplementation at different dosages to prevent vibriosis in white shrimp Litopenaeus vannamei. Hayati Journal of Biosciences 22: 163-168. 